\title{
Chemical and functional properties of different common Brazilian bean (Phaseolus vulgaris L.) cultivars
}

\author{
Propriedades químicas e funcionais de diferentes cultivares de feijão comum brasileiro \\ (Phaseolus vulgaris L.)
}

\author{
Milene Marquezi', Vanessa Maria Gervin'1, Lucas Bertoldi Watanabe', Rodolfo Moresco², Edna Regina Amante ${ }^{\text {* }}$ \\ 1 Universidade Federal de Santa Catarina (UFSC), Centre for Agricultural Sciences, Department of Food Science and Technology, Florianópolis/SC - Brazil \\ 2 Universidade Federal de Santa Catarina (UFSC), Department of Plant Sciences, Florianópolis/SC - Brazil
}

\section{*Corresponding Author}

Edna Regina Amante, Universidade Federal de Santa Catarina (UFSC), Centre for Agricultural Sciences, Department of Food Science and Technology, Rod. Admar Gonzaga, 1346, CEP: 880034-001, Florianópolis/SC - Brazil, e-mail: e.amante@ufsc.br

Cite as: Chemical and functional properties of different common Brazilian bean (Phaseolus vulgaris L.) cultivars. Braz. J. Food Technol., v. 20, e2016006, 2017.

Received: Jan. 18, 2016; Accepted: May 02, 2017

\section{Abstract}

Six different common bean cultivars (BRS Embaixador, BRS Pitanga, BRS Estilo, Pérola, BRS Campeiro and BRS Esplendor) were characterized aiming to determine possible uses for them in various food products. The samples were analysed to determine their chemical composition, weight per hundred beans, $\mathrm{pH}$, water and oil absorption capacities (WAC and OAC, respectively), foaming at $\mathrm{pH} 2.5,5.6$ and 8.0 and emulsifying properties. The relationship between the physicochemical and functional properties was described using the Principal Component Analysis (PCA). The results of the chemical composition, weight per hundred beans, WAC and OAC showed differences even between cultivars of the same commercial group. Foaming also varied between the cultivars and foaming capacity and stability were greatest at $\mathrm{pH} 5.6$ and 8.0. The emulsifying capacity proved quite high for all cultivars, as well as the stability of the emulsion. According to these properties, with the contribution of the PCA, each different bean cultivar can be destined to specific applications according to its physicochemical properties.

Keywords: Chemical characterization; Phaseolus vulgaris L.; Bean cultivars; Bean products.

\section{Resumo}

Seis diferentes cultivares de feijão comum (BRS Embaixador, BRS Pitanga, BRS Estilo, Pérola, BRS Campeiro e BRS Esplendor) foram caracterizados visando suas possíveis utilizações em produtos alimentícios variados. As amostras foram analisadas para determinação da composição química, peso de 100 grãos, pH, capacidade de absorção de água e óleo (CAA e CAO, respectivamente), propriedades espumantes nos $\mathrm{pHs}$ 2,5; 5,6; e 8,0 e propriedades emulsificantes. A relação entre as propriedades físico-químicas e funcionais foi descrita utilizando Análise de Componentes Principais (ACP). Os resultados da composição química, peso de 100 grãos, CAA e CAO mostraram diferenças até mesmo entre cultivares do mesmo grupo comercial. A capacidade de formação de espuma também variou entre os cultivares. A capacidade de formação de espuma e a estabilidade da espuma foram maiores nos pHs 5,6 e 8,0. A capacidade emulsificante foi alta para todos os cultivares bem como a estabilidade da emulsão. De acordo com estas propriedades, com a contribuição da ACP, cada cultivar diferente de feijão pode ser destinado a aplicações específicas, de acordo com as suas propriedades físico-químicas.

Palavras-chave: Caracterização química; Phaseolus vulgaris L.; Cultivares de feijão; Produtos de feijão.

\section{Introduction}

The common bean (Phaseolus vulgaris L.) is the most important food legume used for direct consumption throughout the world. In comparison with other food crops, it has one of the

widest ranges of variation in growth habits, seed characteristics (size, shape, and colour), maturation times and adaptation (JONES, 1999). This grain is an important source of protein, 
complex carbohydrates, minerals and dietary fibres, especially in developing countries (DÍAZ-BATALLA et al., 2006). Bean proteins are rich in lysine, being a good complement to cereal proteins such as rice or corn, which are deficient in this amino acid (GEPTS, 2001).

In spite of these characteristics, beans have some undesirable properties that limit their acceptability and nutritional value, such as the "hard-to-cook" phenomenon, the presence of anti-nutritional factors, and the low nutritional value of its proteins, since they do not contain all the essential amino acids in significant quantities (RAMÍREZ-CÁRDENAS et al., 2008). In the case of beans, anti-nutritional factors such as phytates, protease and amylase inhibitors, lectins and polyphenols (tannins), reduce the activity of some enzymes and the absorption of metabolites (BATISTA et al., 2010).

Although there are studies on the use of beans in bread, pasta and other products (DZUDIE et al., 2002; GALLEGOS-INFANTE et al., 2010; BATISTA et al., 2011), there are few studies linking the development of new products to the characteristics of this raw material, which should be a primary consideration for the development of new bean products, highlighting beans as a function of their important nutritional composition.

Further studies on the different bean cultivars could be the basis for the development of new products, since the industry needs this information in order to select the best variety for use in industrial processing. The purpose of this study was to investigate the properties of different cultivars of red, black and carioca beans in relation to their chemical and functional characteristics, aiming to gather information for future studies on the development of new products and the appropriate modification of current production processes.

\section{Material and methods}

\subsection{Material}

The bean cultivars were provided by EMBRAPA (Goiás, Brazil) and were among the most economically important in Brazil. The cultivars analysed were BRS Embaixador and BRS Pitanga (red), BRS Estilo and Pérola (carioca) and BRS Campeiro and BRS Esplendor (black).

The beans were grown in the experimental fields of EMBRAPA Rice and Beans, in Ponta Grossa, State of Paraná, Brazil, and harvested in May 2011. One hundred gram portions of the beans were stored in polyethylene bags in a cool, dry place until analysed.

\subsection{Sample preparation}

After a preliminary cleaning and the removal of any broken beans, the dried beans were washed with neutral soap and distilled water, and then dried in an oven at $45{ }^{\circ} \mathrm{C}$ for $5 \mathrm{~h}$. The beans were ground in an analytical microprocessor (Q298A21, Quimis ${ }^{\circledR}$, Diadema, Brazil) and the resulting flour sieved (60 mesh). The bean flour samples were vacuum-packed in polyethylene bags and stored at room temperature until analysed.

\subsection{Proximate chemical composition}

The moisture (method 925.10), protein $(N \times 6.25)$ (method 920.87), lipid (method 945.39) and ash (method 942.05) contents of the samples were determined according to the Association of Official Analytical Chemists - AOAC (2005) methods. The carbohydrate content was calculated by the difference from 100. The soluble and insoluble fibre contents were determined using the Total Dietary Fibre kit from Megazyme, based on the AOAC (2005) (methods 985.29, 991.42, 991.43 and 993.19) and American Association for Cereal Chemistry (AACC, 2010) (methods 32-05.01, 32-06.01, 32-07.01 and 32-21-01) methods. The results were expressed on a dry weight basis.

\subsection{Anti-nutritional factors}

The "Phytic Acid (phytate)/Total Phosphorus" kit from Megazyme was used to determine the phytic acid content. The tannins were determined using the vanillin- $\mathrm{HCl}$ method according to Price et al. (1978), preparing the standard curve with catechin (Sigma Chemical Co., St. Louis, Missouri) in methanol, the result being expressed in $\mathrm{mg}$ catechin/g beans. The trypsin inhibitor activity was determined as proposed by Kakade et al. (1974), the results being expressed as units of trypsin inhibitor (UTI) per gram of sample. One unit of inhibitor was responsible for the inhibition of one trypsin unit. The $\alpha$-amylase inhibitor activity was determined using the method proposed by Deshpande et al. (1982). One unit of $\alpha$-amylase inhibitor was defined as the amount of inhibitor that inhibits one unit of $\alpha$-amylase.

\subsection{Functional properties}

The weight per hundred beans was determined by counting out 100 beans, which were then weighed on a semi-analytical balance.

The $\mathrm{pH}$ of the bean samples was recorded using the method proposed by Reyes-Bastidas et al. (2010). The water absorption capacity (WAC) and oil absorption capacity $(O A C)$ of the bean flours were evaluated as proposed by Lin et al. (1974).

The foaming properties were determined as proposed by Siddiq et al. (2010) with modifications. Half-gram (0.5 g) samples of bean flour were dispersed in $50 \mathrm{~mL}$ aliquots of Mcllvaine buffers (disodium phosphate - citric acid) at pH values of 2.5, 5.6 and 8.0. The dispersions were stirred vigorously in a blender (LiqFaz Filter LQ080, Walita ${ }^{\circledR}$ ) for 5 min and then transferred to a graduated cylinder. The volume of the foam that formed was recorded as the 
foaming capacity $\left(\mathrm{mL} \cdot 100 \mathrm{~mL}^{-1}\right)$. The residual volume after 30 minutes was measured to determine foam stability.

The emulsifying properties were determined as proposed by Naczk et al. (1985) with modifications. A sample of the flour $(0.35 \mathrm{~g})$ was homogenized for $30 \mathrm{~s}$ with $5 \mathrm{~mL}$ of water in a Vortex (QL-901, Biomixer ${ }^{\circledR}$, São Paulo, Brazil). Corn oil (2.5 mL) was added and the mixture homogenized again for $30 \mathrm{~s}$. A further $2.5 \mathrm{~mL}$ of corn oil was then added and the mixture homogenized for $90 \mathrm{~s}$ before centrifuging at $1000 \times \mathrm{g}$ for $5 \mathrm{~min}$. The emulsifying capacity was calculated from the relationship between the volume of the emulsified layer and the total volume before centrifugation $\times 100$. The emulsion stability was determined by following the same procedure used to determine the emulsifying capacity, but before centrifuging the samples, they were heated at $85^{\circ} \mathrm{C}$ for 15 min and then centrifuged after cooling. The emulsion stability was expressed as the percentage of the emulsifying activity remaining after heating.

\subsection{Statistical analysis}

All the analyses were performed in triplicate, the results being submitted to an analysis of variance (ANOVA) and the averages compared by applying the Tukey test at $5 \%$ significance, using the Statistica 7.0 software (STATSOFT, 2004). The data on the chemical and technological properties of the bean cultivars analysed were also subjected to a multivariate statistical analysis using the Principal Components Analysis (PCA) method and the Linear Pearson Correlation ( $p<0.05)$, implementing the required script using the $R$ ( $R$ CORE TEAM, 2014) language (v.2.15.2).

\section{Results and discussion}

\subsection{Proximate composition}

The proximate chemical compositions of the samples from the different bean cultivars are shown in Table 1. Differences were found between cultivars of the same group and only the beans of the black group showed no significant differences in protein content. Since all the cultivars came from the same planting site and were subject to the same climatic and environmental conditions, these differences may be related to the cultivars themselves.

The protein content of the bean flours ranged from

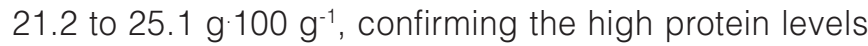
of this legume and consequently its potential as a dietary protein source. Similar results were obtained by Saha et al. (2009), who investigated thirty-five different genotypes of Phaseolus vulgaris L. and noted protein contents that ranged from 18.66 to $26.17 \mathrm{~g} \cdot 100 \mathrm{~g}^{-1}$. Even higher protein levels have been reported by Pujolà et al. (2007), ranging from 23.4 to $32 \mathrm{~g} \cdot 100 \mathrm{~g}^{-1}$.

The insoluble fibre contents ranged from 11.4 to $20.8 \mathrm{~g} 100 \mathrm{~g}^{-1}$, with no significant differences between the insoluble fibre levels of the BRS Estilo and Pérola cultivars. The cultivar BRS Esplendor showed higher insoluble fibre contents than all the other samples.

Kutos et al. (2003) noted similar results for the insoluble and soluble fibre contents of a Phaseolus vulgaris $\mathrm{L}$ cultivar, with an insoluble fibre content of $19.8 \pm 1.4 \mathrm{~g} \cdot 100 \mathrm{~g}^{-1}$ and a soluble fibre content of $3.5 \pm 2.0 \mathrm{~g} \cdot 100 \mathrm{~g}^{-1}$. Wang et al. (2010) investigated seven different common bean cultivars and noted similar quantities of insoluble fibres (from 9.34 to $17.97 \mathrm{~g} \cdot 100 \mathrm{~g}^{-1}$ ) but higher content of soluble fibres (from 3.64 to $5.42 \mathrm{~g}^{1} 100 \mathrm{~g}^{-1}$ ).

The high protein content present in beans supports the idea of preparing protein extracts containing quantities consistent with the solubility and other properties of these proteins.

\subsection{Anti-nutritional factors}

The anti-nutritional factors limit the nutritional quality of beans because they reduce the activity of some enzymes, the biological action of certain chemical compounds, and the absorption of metabolites (RAMÍREZ-CÁRDENAS et al., 2008; BATISTA et al., 2010). Table 2 shows the anti-nutritional contents of the different bean cultivars.

Table 1. Proximate composition of the flours from different bean cultivars ( $\left.\mathrm{g} \cdot 100 \mathrm{~g}^{-1}\right)$.

\begin{tabular}{|c|c|c|c|c|c|c|}
\hline \multirow[b]{2}{*}{$\begin{array}{c}\text { Parameters } \\
\left(\mathbf{g} \cdot 100 \mathbf{~ g}^{-1}\right)\end{array}$} & \multicolumn{2}{|c|}{ Red group } & \multicolumn{2}{|c|}{ Carioca group } & \multicolumn{2}{|c|}{ Black group } \\
\hline & $\begin{array}{c}\text { BRS } \\
\text { Embaixador }\end{array}$ & $\begin{array}{c}\text { BRS } \\
\text { Pitanga }\end{array}$ & $\begin{array}{l}\text { BRS } \\
\text { Estilo }\end{array}$ & Pérola & $\begin{array}{c}\text { BRS } \\
\text { Campeiro }\end{array}$ & BRS Esplendor \\
\hline Carbohydrate & $45.9 \pm 1.4^{b}$ & $37.6 \pm 0.8^{c}$ & $48.9 \pm 0.6^{a}$ & $46.3 \pm 0.4^{a b}$ & $43.8 \pm 1.1^{b}$ & $38.0 \pm 1.6^{c}$ \\
\hline Protein & $23.2 \pm 0.4^{b}$ & $25.1 \pm 0.1^{a}$ & $21.2 \pm 0.1^{c}$ & $22.8 \pm 0.0^{b}$ & $23.6 \pm 0.8^{b}$ & $23.4 \pm 0.6^{b}$ \\
\hline Insoluble fibres & $12.2 \pm 2.0^{c}$ & $18.0 \pm 0.2^{b}$ & $11.4 \pm 0.7^{c}$ & $12.2 \pm 0.1^{c}$ & $16.0 \pm 0.1^{b}$ & $20.8 \pm 0.7^{a}$ \\
\hline Soluble fibres & $2.5 \pm 0.4^{\mathrm{a}}$ & $2.2 \pm 1.2^{\mathrm{a}}$ & $2.6 \pm 0.1^{a}$ & $1.3 \pm 0.1^{\mathrm{ab}}$ & $<0.5 \pm 0.0^{b}$ & $2.2 \pm 0.5^{\mathrm{a}}$ \\
\hline Moisture & $10.8 \pm 0.2^{\mathrm{cd}}$ & $11.9 \pm 0.2^{\mathrm{a}}$ & $10.5 \pm 0.2^{\mathrm{de}}$ & $11.4 \pm 0.2^{\mathrm{ab}}$ & $11.1 \pm 0.2^{b c}$ & $10.1 \pm 0.2^{\mathrm{e}}$ \\
\hline Ash & $4.4 \pm 0.1^{a}$ & $4.1 \pm 0.2^{b c}$ & $3.8 \pm 0.0^{d}$ & $4.3 \pm 0.0^{\mathrm{ab}}$ & $4.0 \pm 0.1^{c d}$ & $4.2 \pm 0.1^{\mathrm{ab}}$ \\
\hline Lipids & $1.0 \pm 0.0^{c}$ & $1.1 \pm 0.1^{c}$ & $1.7 \pm 0.1^{\mathrm{a}}$ & $1.6 \pm 0.1^{a}$ & $1.0 \pm 0.0^{c}$ & $1.4 \pm 0.0^{b}$ \\
\hline
\end{tabular}

Values followed by the same letters in the same row do not differ significantly according to the Tukey test at $5 \%$ probability. 
Table 2. Contents of anti-nutritional factors in the different bean cultivars.

\begin{tabular}{|c|c|c|c|c|c|}
\hline Groups & Cultivars & $\begin{array}{l}\text { Phytic acid } \\
\qquad\left(\mathrm{mg} \cdot \mathrm{g}^{-1}\right)\end{array}$ & $\begin{array}{c}\text { Tannins } \\
\left(\text { mg catechin } \mathbf{g}^{-1}\right)\end{array}$ & $\begin{array}{c}\alpha \text {-Amylase inhibitor } \\
\left(\text { UIA }^{-1}\right)\end{array}$ & $\begin{array}{c}\text { Trypsin inhibitor } \\
\left(\text { UIT } \cdot g^{-1}\right)\end{array}$ \\
\hline \multirow{2}{*}{ Red } & BRS Embaixador & $7.7 \pm 0.2^{\mathrm{a}}$ & $25.8 \pm 2.0^{c}$ & $110.6 \pm 4.4^{c}$ & $1247.7 \pm 37.1^{a}$ \\
\hline & BRS Pitanga & $8.0 \pm 0.4^{\mathrm{a}}$ & $31.1 \pm 2.0^{b}$ & $144.8 \pm 4.4^{\mathrm{a}}$ & $555.1 \pm 28.2^{d}$ \\
\hline \multirow{2}{*}{ Carioca } & BRS Estilo & $7.4 \pm 0.5^{a}$ & $36.2 \pm 1.8^{a}$ & $85.9 \pm 2.9^{d}$ & $865.1 \pm 18.5^{c}$ \\
\hline & Pérola & $7.2 \pm 0.6^{a}$ & $30.6 \pm 1.6^{b}$ & $121.1 \pm 4.5^{b}$ & $973.7 \pm 8.0^{b}$ \\
\hline \multirow{2}{*}{ Black } & BRS Campeiro & $7.3 \pm 0.1^{a}$ & $15.1 \pm 0.4^{d}$ & $153.7 \pm 2.9^{a}$ & $465.2 \pm 23.4^{\mathrm{e}}$ \\
\hline & BRS Esplendor & $8.2 \pm 0.6^{a}$ & $18.1 \pm 0.9^{d}$ & $92.8 \pm 1.4^{d}$ & $502.2 \pm 6.4^{\mathrm{de}}$ \\
\hline
\end{tabular}

Values followed by the same letters in the same column do not differ significantly according to the Tukey test at $5 \%$ probability.

The phytic acid contents ranged from 7.2 to $8.2 \mathrm{mg} \mathrm{g}^{-1}$ and showed no significant differences between cultivars. Deshpande et al. (1982) noted higher values for phytic acid, ranging from 11.6 to $29.3 \mathrm{mg}^{-1}$ when the whole beans were analysed and the phytic acid contents of shelled beans ranged from 16.3 to $36.1 \mathrm{mg} \cdot \mathrm{g}^{-1}$. The results of these authors showed that the phytic acid was predominantly present in the cotyledon.

The condensed tannin contents of the cultivars ranged from 15.1 to $36.2 \mathrm{mg}$ catechin $\mathrm{g}^{-1}$. It can be seen that for the same group, only the black group (BRS Campeiro and BRS Esplendor) showed no significant differences. BRS Estilo was the cultivar with the highest tannin content.

The $\alpha$-amylase inhibitor concentrations ranged from 85.91 to $153.74 \mathrm{UAl} \cdot \mathrm{g}^{-1}$ and the trypsin inhibitor contents from 465.19 to $1247.67 \mathrm{UTI} \cdot \mathrm{g}^{-1}$. Batista et al. (2010) noted $\alpha$-amylase inhibitor contents of 18.16 and $16.08 \mathrm{UAl} \cdot 100 \mathrm{mg}^{-1}$ and higher values for the trypsin inhibitor, 4.64 and $4.61 \mathrm{UTI}^{-\mathrm{mg}^{-1}}$ (4640 and 4610 UTI.g $^{-1}$ ) for the cultivars BRS Pontal (carioca) and BRS Grafite (black).

Comparing the anti-nutritional factor levels of the bean cultivars with those of other legumes, it can be seen that for chickpeas the phytic acid $\left(1.21 \mathrm{mg}^{-1}\right)$ and tannin $\left(4.85 \mathrm{mg}^{-1} \mathrm{~g}^{-1}\right.$ contents were lower, but the trypsin inhibitor content (11.9 UTI. $\mathrm{mg}^{-1}$ ) was much higher than that found for the six bean cultivars analysed by Alajaji and El-Adawy (2006). For peas, the phytic acid $\left(0.815 \mathrm{~g}^{1} 100 \mathrm{~g}^{-1}\right)$, tannin (30.93 $\mathrm{mg} \mathrm{g}^{-1}$ ) and trypsin inhibitor (1297.22 UTI. $\mathrm{mg}^{-1}$ ) contents were similar to those found for the bean cultivars, except for the trypsin inhibitor, for which the results were only close only to those found for BRS Embaixador (KHATTAB; ARNTFIELD, 2009).

\subsection{Weight per hundred beans, $\mathrm{pH}$, and water and oil absorption capacities}

Table 3 shows the data found for the physical parameters of the cultivars. The weight per hundred beans ranged from 19.99 to $46.00 \mathrm{~g}$. and cultivars belonging to the same group showed significant differences for these weights. The weight per hundred beans of BRS Embaixador was significantly higher than that of the other cultivars. This cultivar is physically characterized by its large beans.

The $\mathrm{pH}$ values of the bean flours were close to neutral for all the cultivars. BRS Embaixador and BRS Estilo showed higher $\mathrm{pH}$ values than the other cultivars. These results are similar to those obtained by Reyes-Bastidas et al. (2010), in which the $\mathrm{pH}$ values of both the non-fermented and fermented bean flours of the cultivar studied were 6.42 and 6.34 , respectively.

The water absorption capacity of the bean flours ranged from 123.4 to $138.0 \%$. Water absorption capacity is important for certain product characteristics, such as moistness and starch retrogradation with subsequent product hardening (SATHE, 2002). Dzudie et al. (2002) evaluated the effect of replacing meat with bean flour in sausages, and found that the greater the amount of bean flour added to the sausages, the greater their capacity to retain water when compared to the control. In addition, there was an increased yield for the cooked sausages, due to reduced cooking losses.

The oil absorption capacity of the samples ranged from 86.4 to $98.2 \%$. The oil absorption capacity of bean flour is important in the development of new fried products, as well as for its stability during storage (SATHE, 2002). Siddiq et al. (2010) reported that the WAC and OAC values of the flour samples from different bean cultivars ranged from 223 to $265 \%$ and from 123 to $152 \%$, respectively. The results obtained by these authors were higher than those shown in Table 3. These values may vary according to the cultivar and planting location. However, the values noted by Sathe and Salunkhe (1981), who studied only one cultivar, were close to those obtained for the cultivars studied in the present work. These authors observed that the protein concentrate showed higher WAC and OAC values when compared to the bean flour, and therefore concluded that the type, quantity and structure of the proteins in the beans affected these physical properties, the same occurring for the starch and cellulose, and other carbohydrates. 
Table 3. Weight per hundred beans, water absorption capacity (WAC), oil absorption capacity (OAC) and pH in different cultivars.

\begin{tabular}{|c|c|c|c|c|c|}
\hline Groups & Cultivars & $\begin{array}{l}\text { Weight per } 100 \\
\text { beans } \\
\text { (g) }\end{array}$ & pH & $\begin{array}{c}\text { WAC } \\
(\%)\end{array}$ & $\begin{array}{c}\text { OAC } \\
(\%)\end{array}$ \\
\hline \multirow{2}{*}{ Red } & BRS Embaixador & $46.00 \pm 0.21^{a}$ & $6.46 \pm 0.01^{a}$ & $137.9 \pm 2.0^{a}$ & $98.2 \pm 0.2^{a}$ \\
\hline & BRS Pitanga & $19.99 \pm 0.04^{e}$ & $6.32 \pm 0.02^{b}$ & $123.7 \pm 4.4^{b}$ & $96.8 \pm 2.0^{a}$ \\
\hline \multirow{2}{*}{ Carioca } & BRS Estilo & $26.47 \pm 0.22^{c}$ & $6.42 \pm 0.02^{a}$ & $131.6 \pm 1.0^{a}$ & $86.4 \pm 1.4^{b}$ \\
\hline & Pérola & $28.42 \pm 0.25^{b}$ & $6.31 \pm 0.02^{b}$ & $138.0 \pm 0.9^{a}$ & $95.4 \pm 0.5^{a}$ \\
\hline \multirow{2}{*}{ Black } & BRS Campeiro & $26.85 \pm 0.22^{c}$ & $6.32 \pm 0.02^{b}$ & $130.2 \pm 4.3^{\mathrm{ab}}$ & $96.3 \pm 3.8^{a}$ \\
\hline & BRS Esplendor & $21.33 \pm 0.07^{d}$ & $6.32 \pm 0.02^{b}$ & $137.4 \pm 2.1^{\mathrm{a}}$ & $89.6 \pm 2.0^{b}$ \\
\hline
\end{tabular}

Values followed by the same letters in the same column do not differ significantly according to the Tukey test at $5 \%$ probability.

\subsection{Foaming and emulsion properties}

The foaming capacity and foam stability of the bean cultivars at different $\mathrm{pH}$ values are shown in Table 4.

For BRS Estilo, Pérola and BRS Esplendor cultivars the highest degree of foam capacity occurred at $\mathrm{pH} 8.0$ $(p<0.05)$. A decrease in the hydrophobic attractive forces between protein molecules occurs at $\mathrm{pH}$ values within the acid and alkaline ranges, where the protein molecules become positively and negatively charged, respectively. According to Chau and Cheung (1998), charges with the same sign lead to repulsion, thus facilitating flexibility of the protein molecules and causing them to spread more rapidly toward the air-water interface and encapsulate air particles, leading to foaming.

The foam stability at different $\mathrm{pH}$ levels presented a distinctive behaviour for each cultivar investigated. BRS Embaixador presented greater stability at $\mathrm{pH} 2.5$ and 5.6; BRS Pitanga and BRS Campeiro at pH 5.6; and BRS Estilo and Esplendor at pH 8.0. Adebowale and Lawal (2003) studied the foaming ability of a mucana bean (Mucana pruriens) protein concentrate and found a $35 \%$ increase in the foaming capacity at $\mathrm{pH} 4$ while the maximum foaming was $134 \%$ at $\mathrm{pH} 10$. Furthermore, an increase in foaming capacity was observed at $\mathrm{pH} 2$. The highest foam stability over 8 hours was noted at pH 4 (close to the isoelectric region).

Considering the chemical composition of beans, especially the high protein content, the emulsifying properties should be studied for future applications, such as the use of this raw material to produce vegetable spreads and soups.

The values for emulsifying capacity (Table 5) varied between 68.3 and $72.9 \%$. BRS Pitanga and Pérola were the only cultivars that differed significantly in terms of emulsion formation. In the case of emulsion stability, these cultivars also differed significantly from each other, and BRS Embaixador showed significant differences when compared to Pérola, BRS Campeiro and BRS Esplendor.

Siddiq et al. (2010) evaluated the physical and functional characteristics of bean flour and observed emulsifying capacities ranging between $45.6 \%$ and $60.5 \%$. The stability of the emulsions for the same cultivars varied between $48.2 \%$ and $62.3 \%$. Although the emulsifying stability showed higher values when compared to the emulsifying capacity, the values were lower than those observed in the present study.

Studies to investigate the foaming and emulsifying properties of products made from beans are scarce and thus greater attention needs to be given to these properties.

\subsection{Principal component analysis}

The principal component analysis, when applied to the data of the chemical and technological properties analysed, revealed that components 1 and 2 explained $24.4 \%$ and $42.6 \%$ of the variation, respectively, expressing $67.0 \%$ of the total variation (Figure 1). The ash and lipid variables were not added to the PCA because their low levels would not contribute significantly to the other variables, and nor were the $\mathrm{pH}$ values of the beans or the weight per 100 beans. The $\mathrm{pH}$ of choice for both the foaming capacity and the foam stability was 5.6 , since this $\mathrm{pH}$ is nearest to the physiological $\mathrm{pH}$ value and that of the food processing conditions.

There was an acceptable distribution between the bean cultivars studied, allowing one to infer specific characteristics for each of them, as determined by the location next to the PCA eigenvectors.

The water absorption capacity variable (PC1-/PC2-) was negatively correlated with the oil absorption capacity in $\mathrm{PC} 1+/ \mathrm{PC} 2+(r=-0.099$, Pearson linear correlation, $p<0.05$ ), and the Pérola cultivar was closest to the eigenvectors of water absorption capacity and emulsifying capacity, indicating that this cultivar obtained high values for these variables, as can be seen in Tables 3 and 5, respectively. The cultivar BRS Estilo contained higher levels of carbohydrates and tannins, explaining why the eigenvectors of these parameters were pointing in its direction.

The tannins and trypsin inhibitor variables showed positive correlation $(r=+0.481, p<0.05)$ on PC1- and PC2+. 
Table 4. Foaming capacity and foam stability at pH 2.5, 5.6 and 8.0 for the different bean cultivars.

\begin{tabular}{|c|c|c|c|c|c|c|c|}
\hline \multirow{2}{*}{ Group } & \multirow{2}{*}{ Cultivars } & \multicolumn{3}{|c|}{ Foaming capacity (mL.100 mL $\mathrm{m}^{-1}$ ) } & \multicolumn{3}{|c|}{ Foam stability (mL.100 $\mathrm{mL}^{-1}$ ) } \\
\hline & & pH 2.5 & pH 5.6 & pH 8.0 & pH 2.5 & pH 5.6 & pH 8.0 \\
\hline \multirow{2}{*}{ Red } & BRS Embaixador & $53.0 \pm 2.8^{\mathrm{abA}}$ & $56.4 \pm 2.5^{\mathrm{abA}}$ & $35.9 \pm 4.2^{\mathrm{dB}}$ & $42.5 \pm 1.3^{\mathrm{aA}}$ & $43.1 \pm 0.4^{\mathrm{aA}}$ & $24.5 \pm 0.6^{\mathrm{eB}}$ \\
\hline & BRS Pitanga & $59.1 \pm 0.6^{\mathrm{aB}}$ & $62.5 \pm 2.2^{\mathrm{aA}}$ & $57.2 \pm 0.8^{\mathrm{bB}}$ & $33.4 \pm 2.8^{\mathrm{bcc}}$ & $47.3 \pm 2.8^{\mathrm{aA}}$ & $41.6 \pm 0.8^{\mathrm{bB}}$ \\
\hline \multirow{2}{*}{ Carioca } & BRS Estilo & $48.2 \pm 3.5^{\mathrm{bcB}}$ & $47.4 \pm 1.0^{\mathrm{cB}}$ & $63.9 \pm 2.5^{\mathrm{aA}}$ & $34.8 \pm 4.0^{\mathrm{bcB}}$ & $36.1 \pm 1.2^{\mathrm{bcB}}$ & $48.0 \pm 0.7^{\mathrm{aA}}$ \\
\hline & Pérola & $45.6 \pm 2.9^{\mathrm{cdB}}$ & $33.7 \pm 1.7^{\mathrm{dC}}$ & $53.5 \pm 2.3^{\mathrm{bcA}}$ & $31.0 \pm 0.6^{\mathrm{bcB}}$ & $30.5 \pm 1.0^{с \mathrm{~B}}$ & $38.4 \pm 2.6^{\mathrm{bcA}}$ \\
\hline \multirow{2}{*}{ Black } & BRS Campeiro & $53.1 \pm 2.9^{\mathrm{abA}}$ & $55.4 \pm 3.0^{\mathrm{bA}}$ & $50.5 \pm 1.5^{\mathrm{cA}}$ & $37.2 \pm 3.1^{\mathrm{abB}}$ & $42.0 \pm 2.5^{\mathrm{abA}}$ & $30.3 \pm 3.1^{d c}$ \\
\hline & BRA Esplendor & $41.1 \pm 0.7^{\mathrm{dB}}$ & $43.2 \pm 3.4^{\mathrm{cB}}$ & $50.0 \pm 1.7^{\mathrm{cA}}$ & $28.9 \pm 1.1^{\mathrm{CB}}$ & $32.7 \pm 3.6^{\mathrm{cA}}$ & $34.7 \pm 2.5^{\mathrm{cdA}}$ \\
\hline
\end{tabular}

Values followed by the same small letters in the same column do not differ significantly according to the Tukey test at $5 \%$ probability. Values followed by the same capital letters in the same row do not differ significantly according to the Tukey test at $5 \%$ probability.

Table 5. Emulsifying capacity and emulsion stability for the different bean cultivars.

\begin{tabular}{cccc} 
Groups & Cultivars & Emulsifying capacity (\%) & Emulsion stability (\%) \\
Red & BRS Embaixador & $71.2 \pm 2.4^{\mathrm{ab}}$ & $68.9 \pm 2.4^{\mathrm{b}}$ \\
& BRS Pitanga & $68.3 \pm 1.2^{\mathrm{b}}$ & $69.6^{\mathrm{b}} \pm 3.0^{\mathrm{b}}$ \\
Carioca & BRS Estilo & $71.7 \pm 1.9^{\mathrm{ab}}$ & $72.9 \pm 1.8^{\mathrm{ab}}$ \\
& Pérola & $72.9 \pm 2.1^{\mathrm{a}}$ & $77.3 \pm 0.6^{\mathrm{a}}$ \\
Black & BRS Campeiro & $71.2 \pm 1.1^{\mathrm{ab}}$ & $76.2 \pm 2.4^{\mathrm{a}}$ \\
& BRS Esplendor & $72.6 \pm 0.6^{\mathrm{ab}}$ & $76.1 \pm 0.6^{\mathrm{a}}$ \\
\hline
\end{tabular}

Values followed by the same letters in the same column do not differ significantly according to the Tukey test at $5 \%$ probability.

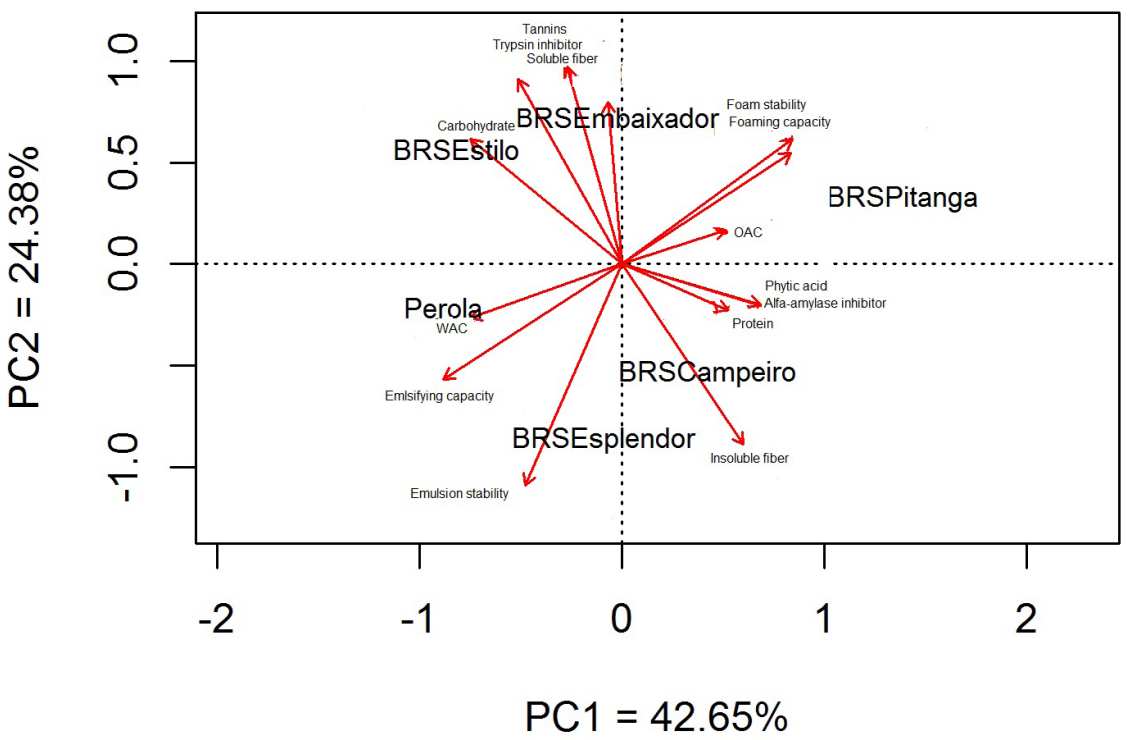

Figure 1. Principal Component Analysis of the chemical and functional properties of different common bean cultivars.

This relationship was due to the tendency of tannins to form complexes with proteins, damaging the stereochemistry of these macromolecules (SCHOFIELD et al., 2001). Since trypsin is a protein, it can be complexed by tannins thus inhibiting its enzymatic action and reducing bean digestibility (HE et al., 2006; GONÇALVES et al., 2011). In addition to the tannins and trypsin inhibitor, phytic acid and the $\alpha$-amylase inhibitor also correlated positively on PC1+ and PC2-, just due to the action of phytic acid in inhibiting amylolytic enzymes. Phytic acid complexes mono- and divalent ions such as calcium. Calcium, in turn, is a cofactor of the $\alpha$-amylase enzyme. Thus, phytic acid can reduce the activity of $\alpha$-amylase by complexation with calcium, acting as an inhibitor of this enzyme (CAWLEY; MITCHELL, 1968; LI et al., 1993).

The variables of foaming capacity and foam stability were positively correlated with each other $(r=+0.98$, $p<0.05)$ and with the oil absorption capacity $(r=+0.411$ and +0.548 , respectively, $p<0.05$ ) on PC1+/PC2+. Moreover, even when considering only the first principal component, these variables also correlated positively with proteins on $\mathrm{PC} 1+$. The hydrophobic portion of the protein promotes the 
formation of the foam as well as its stability, and also the oil absorption capacity. The increased hydrophobicity helps to bind the oil and decreases the interfacial tension of the foam, thus increasing its stability, since the hydrophobic region of the protein increases resistance to migration into the aqueous phase (KESHAVARZ; NAKAI, 1979; NAKAI, 1983).

The emulsifying capacity and emulsion stability were positively correlated with each other $(r=+0.714, p<0.05)$ and with the water absorption capacity $(r=+0.871$ and +0.366 , respectively, $p<0.05)$ on PC1-/PC2-. These variables also correlated with the carbohydrate content on PC1- $(r=+0.45$ for emulsifying capacity, $r=+0.072$ for emulsion stability, $r=+0.37$ for the water absorption capacity). Carbohydrates act by enhancing the water absorption capacity, and the large amounts present in the bean cultivars studied may have contributed to the positive correlation between these variables.

Starch represents a considerable proportion of the carbohydrates present in beans. Pujolà et al. (2007) investigated nine bean cultivars and found starch contents ranging from $41.4 \%$ to $52.3 \%$. The high starch content justifies the correlation with the water absorption capacity, since it can swell when in contact with water, retaining the water and thus also acting as an emulsifier ( $L I$ et al., 2013; TIMGREN et al., 2013).

The emulsifying capacity and emulsion stability were positively correlated with each other $(r=+0.714, p<0.05)$ and with the water absorption capacity $(r=+0.871$ and +0.366 , respectively, $\mathrm{p}<0.05)$ on $\mathrm{PC} 1$-/PC2-.These variables were also correlated with the carbohydrate content on PC1- $(r=+0.45$ for emulsifying capacity; $r=+0.072$ for emulsion stability; and $r=+0.37$ for water absorption capacity).

\section{Conclusions}

The results of this study revealed differences in the chemical and functional properties of the bean cultivars commonly used in Brazil. There were significant differences amongst the cultivars, even between those belonging to the same commercial colour group. However, despite the differences, all the bean cultivars had high protein and fibre contents, indicating that the bean flours could be used as a complement to wheat flour, increasing the nutritional quality of the food.

The foaming capacity occurred at $\mathrm{pH}$ values specific for each cultivar. However, foam stability was greatest at $\mathrm{pH}$ values of 5.6 and 8.0. The emulsifying capacity was shown to be quite high for all cultivars, as well as the emulsion stability.

By way of the PCA applications for the cultivars could be established according to their physicochemical properties, with the possibility to preview practical uses in the food industries. Data on the physicochemical properties are important in the development of new products that are based on bean flour, in order to provide references for the quality control of the raw material. One area where bean flour could be used is in the development gluten-free products.

Soybeans, peanuts and chickpeas are already used in products that have good consumer acceptance. Similarly, bean products could gain such prominence and become another differential source of nutrients and of products with high consumer acceptability.

\section{Acknowledgements}

The authors are grateful to: Dr. Priscila Zaczuc Bassinello, EMBRAPA Rice and Bean, Santo Antônio de Goiás, Brazil; CNPq.

\section{References}

ADEBOWALE, K. O.; LAWAL, O. S. Foaming, gelation and electrophoretic characteristics of mucana bean (Mucana pruriens) protein concentrates. Food Chemistry, v. 83, n. 2, p. 237-246, 2003. http://dx.doi.org/10.1016/S0308-8146(03)00086-4.

ALAJAJI, S. A.; EL-ADAWY, T. A. Nutritional composition of chickpea (Cicer arietinum L.) as affected by microwave cooking and other traditional cooking methods. Journal of Food Composition and Analysis, v. 19, n. 8, p. 806-812, 2006. http://dx.doi.org/10.1016/j. jfca.2006.03.015.

AMERICAN ASSOCIATION OF CEREAL CHEMISTS - AACC. Official methods of American Association of Cereal Chemists. 11th ed. Saint Paul: AACC, 2010.

ASSOCIATION OF OFFICIAL ANALYTICAL CHEMISTIS - AOAC. Official methods of Analysis of the Association of Official Analytical Chemists. 18th ed. Gaithersburg: AOAC, 2005.

BATISTA, K. A.; PRUDÊNCIO, S. H.; FERNANDES, K. F. Changes in the functional properties and antinutritional factors of extruded hard-to-cook common beans (Phaseolus vulgaris L.). Journal of Food Science, v. 75, n. 3, p. C286-C290, 2010. PMid:20492281. http://dx.doi.org/10.1111/j.1750-3841.2010.01557.x.

BATISTA, K. A.; PRUDÊNCIO, S. H.; FERNANDES, K. F. Wheat bread enrichment with hard-to-cook bean extruded flours: nutritional and acceptance evaluation. Journal of Food Science, v. 76, n. 1, p. S108-S113, 2011. PMid:21535708. http://dx.doi. org/10.1111/j.1750-3841.2010.01969.x.

CAWLEY, R. W.; MITCHELL, T. A. Inhibition of wheat $\alpha$-amylase by bran phytic acid. Journal of the Science of Food and Agriculture, v. 19, n. 2, p. 106-108, 1968. http://dx.doi.org/10.1002/ jsfa.2740190210.

CHAU, C. F.; CHEUNG, P. C. K. Functional properties of flours prepared from three Chinese indigenous legume seeds. Food 
Chemistry, v. 61, n. 4, p. 429-433, 1998. http://dx.doi.org/10.1016/ S0308-8146(97)00091-5

DESHPANDE, S. S.; SATHE, S. K.; SALUNKHE, D. K.; CORNFORTH, D. P. Effects of dehulling on phytic acid, polyphenols, and enzyme inhibitors of dry beans (Phaseolus vulgaris L.). Journal of Food Science, v. 47, n. 6, p. 1846-1850, 1982. http://dx.doi. org/10.1111/j.1365-2621.1982.tb12896.x.

DÍAZ-BATALLA, L.; WIDHOLM, J. M.; FAHEY JUNIOR, G. C.; CASTAÑO-TOSTADO, E.; PAREDES-LÓPEZ, O. Chemical components with health implications in wild and cultivated mexican common beans seeds (Phaseolus vulgaris L.). Journal of Agricultural and Food Chemistry, v. 56, n. 6, p. 2045-2052, 2006. PMid:16536573. http://dx.doi.org/10.1021/jf051706l.

DZUDIE, T.; SCHER, J.; HARDY, J. Common bean flour as an extender in beef sausages. Journal of Food Engineering, v. 52, n. 2, p. 143-147, 2002. http://dx.doi.org/10.1016/S02608774(01)00096-6.

GALLEGOS-INFANTE, J. A.; ROCHA-GUZMAN, N. E.; GONZALEZ-LAREDO, R. F.; OCHOA-MARTÍNEZ, L. A.; CORZO, N.; BELLO-PEREZ, L. A.; MEDINA-TORRES, L.; PERALTA ALVAREZ, L. E. Quality of spaghetti pasta containing Mexican common bean flour (Phaseolus vulgaris L.). Food Chemistry, v. 119, n. 4, p. 1544-1549, 2010. http://dx.doi.org/10.1016/j. foodchem.2009.09.040.

GEPTS, P. Phaseolus vulgaris (Beans). In: BRENNER, S.; MILLER, J. H. (Ed.). Encyclopedia of genetics. Cambridge: Academic Press, 2001. p. 1444-1445.

GONÇALVES, R.; NUNO, M.; PIANET, I.; LAGUERRE, M.; FREITAS, $V$. Mechanisms of tannin-induced trypsin inhibition: a molecular approach. Langmuir, v. 27, n. 21, p. 13122-13129, 2011.

HE, Q.; LV, Y.; YAO, K. Effects of tea polyphenols on the activities of $\alpha$-amylase, pepsin, trypsin and lipase. Food Chemistry, $v$. 101, n. 2, p. 1178-1182, 2006.

JONES, A. L. Phaseolus bean: post-harvest operations. Roma: FAO, 1999. Available at: <http://www.fao.org/>. Accessed on: 15 Aug. 2012

KAKADE, M. L.; RACKIS, J. L.; MCGUEE, J. E.; PUSKI, G. Determination of trypsin inhibitor activity of soy bean products: a collaborative analysis of an improved procedure. Cereal Chemistry, v. 51, p. 376-382, 1974.

KESHAVARZ, E.; NAKAI, S. The relationship between hydrophobicity and interfacial tension of proteins. Biochimica et Biophysica Acta, v. 576, n. 2, p. 269-279, 1979. PMid:427187. http://dx. doi. org/10.1016/0005-2795(79)90402-1.

KHATTAB, R. Y.; ARNTFIELD, S. D. Nutritional quality of legume seeds as affected by some physical treatments 2 . Antinutritional factors. Food Science and Technology, v. 42, n. 6, p. 11131118, 2009.
KUTOS, T.; GOLOB, T.; KAC, M.; PLESTENJAK, A. Dietary fibres content of dry and processed beans. Food Chemistry, v. 80 , n. 2, p. 231-235, 2003. http://dx.doi.org/10.1016/S03088146(02)00258-3.

LI, C.; LI, Y.; SUN, P.; YANG, C. Pickering emulsions stabilized by native starch granules. Colloids and Surfaces. A, Physicochemical and Engineering Aspects, v. 431, p. 142-149, 2013. http:// dx.doi.org/10.1016/j.colsurfa.2013.04.025.

LI, Z.; ALLI, I.; KERMASHA, S. In-vitro $\alpha$-amylase inhibitor activityphytate relationships in proteins from Phaseolus beans. Food Research International, v. 26, n. 3, p. 195-201, 1993. http:// dx.doi.org/10.1016/0963-9969(93)90053-L.

LIN, M. J. Y.; HUMBERT, E. S.; SOSULSKI, F. W. Certain functional properties of sunflower meal products. Journal of Food Science, v. 39, n. 2, p. 368-370, 1974. http://dx.doi. org/10.1111/j.1365-2621.1974.tb02896.x.

NACZK, M.; DIOSADY, L. L.; RUBIN, L. J. Functional properties of canola meals produced by a two-phase solvent extraction system. Journal of Food Science, v. 50, n. 6, p. 1685-1692, 1985. http://dx.doi.org/10.1111/j.1365-2621.1985.tb10565.x.

NAKAI, S. Structure-function relationships of food proteins with an emphasis on the importance of protein hydrophobicity. Journal of Agricultural and Food Chemistry, v. 31, n. 4, p. 676-683, 1983. http://dx.doi.org/10.1021/jf00118a001.

PRICE, M. L.; VAN SCOYOC, S.; BUTLER, L. G. A critical evaluation of the vanillin reaction as an assay for tannin in sorghum grain. Journal of Agricultural and Food Chemistry, v. 26, n. 5, p. 1214-1218, 1978. http://dx.doi.org/10.1021/jf60219a031.

PUJOLÀ, M.; FARRERAS, A.; CASAÑAS, F. Protein and starch content of raw, soaked and cooked beans (Phaseolus vulgaris L.). Food Chemistry, v. 102, n. 4, p. 1034-1041, 2007. http:// dx.doi.org/10.1016/j.foodchem.2006.06.039.

R CORE TEAM. R: a language and environment for statistical computing. Vienna: R Foundation for Statistical Computing, 2014. Available at: <http://www.R-project.org/>. Accessed on: 9 mar. 2015

RAMÍREZ-CÁRDENAS, L.; LEONEL, A. J.; COSTA, N. M. B. Effect of domestic processing on nutrient and antinutritional factor content in different cultivars of common beans. Ciência e Tecnologia de Alimentos, v. 28, n. 1, p. 200-213, 2008.

REYES-BASTIDAS, M.; REYES-FERNÁNDEZ, E. Z.; LÓPEZCERVANTES, J.; MILÁN-CARRILLO, J.; LOARCA-PIÑA, G. F.; REYES-MORENO, C. Physicochemical, nutritional and antioxidant properties of tempeh flour common bean (Phaseolus vulgaris L.). Food Science \& Technology International, v. 16, n. 5, p. 427-434, 2010. PMid:21339161. http://dx.doi.org/10.1177/1082013210367559.

SAHA, S.; SINGH, G.; MAHAJAN, V.; GUPTA, H. S. Variability of nutritional and cooking quality in bean (Phaseolus vulgaris L.) as a function of genotype. Plant Foods for Human Nutrition, v. 64, n. 2, p. 174-180, 2009. PMid:19462242. http://dx.doi. org/10.1007/s11130-009-0121-4. 
Chemical and functional properties of different common Brazilian bean (Phaseolus vulgaris L.) cultivars Marquezi, M. et al.

SATHE, S. K. Dry bean protein functionality. Critical Reviews in Biotechnology, v. 22, n. 2, p. 175-223, 2002. PMid:12135167. http://dx.doi.org/10.1080/07388550290789487.

SATHE, S. K.; SALUNKHE, D. K. Functional properties of the Great Northern Bean (Phaseolus vulgaris L.) proteins: emulsion, foaming, viscosity, and gelation properties. Journal of Food Science, v. 46, n. 1, p. 71-75, 1981. http://dx.doi.org/10.1111/j.1365-2621.1981. tb14533.x.

SCHOFIELD, P.; MBUGUA, D. M.; PELL, A. N. Analysis of condensed tannins: a review. Animal Feed Science and Technology, $v$. 91, n. 1-2, p. 21-40, 2001. http://dx.doi.org/10.1016/S03778401(01)00228-0

SIDDIQ, M.; RAVI, R.; HARTE, J. B.; DOLAN, K. D. Physical and functional characteristics of selected dry bean (Phaseolus vulgaris L.) flours. Food Science and Technology-LWT, v. 43, n. 2, p. 232-237, 2010. http://dx.doi.org/10.1016/j.Iwt.2009.07.009.

STATSOFT. Statistic for Windows. versão 7.0. Tulsa: StatSoft Inc., 2004

TIMGREN, A.; RAYNER, M.; DEJMEK, P.; MARKU, D.; SJÖÖ, M. Emulsion stabilizing capacity of intact starch granules modified by heat treatment or octenyl succinic anhydride. Food Science \& Nutrition, v. 1, n. 2, p. 157-171, 2013. PMid:24804025. http:// dx.doi.org/10.1002/fsn3.17.

WANG, N.; HATCHER, D. W.; TYLER, R. T.; TOEWS, R.; GAWALKO, E. J. Effect of cooking on the composition of bean (Phaseolus vulgaris L.) and chickpeas (Cicer arietinum L.). Food Research International, v. 43, n. 2, p. 589-594, 2010. http://dx.doi. org/10.1016/j.foodres.2009.07.012. 